\title{
Therapeutic effect of bortezomib for primary plasma cell leukemia followed by auto/allo stem cell transplantation
}

This article was published in the following Dove Press journal:

International Medical Case Reports Journal

5 July 2012

Number of times this article has been viewed

\section{Ryotaro Ozasa \\ Masaaki Hotta \\ Hideaki Yoshimura \\ Takahisa Nakanishi \\ Takeshi Tamaki \\ Shinya Fujita \\ Naoto Nakamichi \\ Michihiko Miyaji \\ Kazuyoshi Ishii \\ Tomoki Ito \\ Shosaku Nomura}

First Department of Internal Medicine, Kansai Medical University, Osaka, Japan
Correspondence: Shosaku Nomura 10-15, Fumizono-Cho, Moriguchi City, Osaka $570-8507$, Japan

Tel +81669939453

Fax +81669921293

Email nomurash@hirakata.kmu.ac.jp
Abstract: Plasma cell leukemia (PCL) is a rare disease that represents approximately $4 \%$ of plasma cell malignant disorders. PCL consists of two variants: primary PCL presents in patients with no previous history of multiple myeloma, while secondary PCL consists of a leukemic transformation in a previously recognized multiple myeloma. Primary PCL is an extremely resistant, rapidly progressive, fatal disease, with a median overall survival of 6.8 months. There is no standard therapeutic strategy, because no treatment option has been prospectively evaluated. We describe a successful case of newly diagnosed primary PCL, treated with a regimen that included bortezomib, followed by auto stem cell transplantation and nonmyeloablative allogeneic stem cell transplantation. Our patient has maintained remission status for over 12 months since undergoing the allogeneic stem cell transplantation. This strategy is promising for PCL, which, though an extremely resistant disease, may become curable.

Keywords: plasma cell leukemia, multiple myeloma, bortezomib, stem cell transplantation

\section{Introduction}

Plasma cell leukemia (PCL) is a rare disease that represents approximately $4 \%$ of plasma cell malignant disorders. ${ }^{1}$ Diagnosis of PCL is established based on Kyle's criteria, which includes an absolute plasma cell number accounting for greater than $2000 / \mu \mathrm{L}$ or $20 \%$ of white blood cell differentiation. ${ }^{2}$ PCL consists of two variants: primary PCL presents in patients with no previous history of multiple myeloma (MM), while secondary PCL consists of a leukemic transformation in previously recognized MM. ${ }^{3}$ Primary PCL is an extremely resistant, rapidly progressive, fatal disease, with a median overall survival of 6.8 months. ${ }^{4}$ There is no standard therapeutic strategy, because none of the treatment options have been prospectively evaluated. We describe herein a successful case of newly diagnosed primary PCL, treated with a regimen that included bortezomib, followed by auto stem cell transplantation (ASCT) and nonmyeloablative allogeneic stem cell transplantation (allo-SCT).

\section{Case report}

A 37-year-old man with suspected primary PCL was sent from a nearby hospital to our institution in February 2010. His symptoms were slight fever, dyspnea, and a wet cough. Table 1 shows the laboratory data of the initial medical examination, and Table 2 shows the data on admission to our hospital. The white blood cell count and its differentiation met Kyle's criteria. Renal dysfunction caused by hypercalcemia had already been successfully treated at a nearby hospital. Hypoglobulinemia was present instead of M-proteinemia. Serum $\kappa / \lambda$ was extremely low $(0.25)$. The patient 
Table I Laboratory data at initial medical examination

\begin{tabular}{|c|c|}
\hline Variable & On admission \\
\hline WBC $(/ \mu \mathrm{L})$ & $14,280(3,300-9,800)$ \\
\hline Neutrophils (\%) & $29(48-6 I)$ \\
\hline Lymphocytes (\%) & $20(25-45)$ \\
\hline Blasts (\%) & $0(0)$ \\
\hline Others (\%) & $34(0)$ \\
\hline Erythrocytes (/WI00) & I \\
\hline $\mathrm{RBC}\left(\times 10^{6} / \mu \mathrm{L}\right)$ & $221(4 \mid 7-525)$ \\
\hline $\mathrm{Hb}(\mathrm{g} / \mathrm{dL})$ & $7.5(13.0-17.6)$ \\
\hline $\mathrm{Ht}(\%)$ & $23.3(42-52)$ \\
\hline Plt $\left(\times 10^{6} / \mu \mathrm{L}\right)$ & $3.4(13-35)$ \\
\hline $\mathrm{Na}(\mathrm{mEq} / \mathrm{L})$ & I4I (135-I45) \\
\hline $\mathrm{K}(\mathrm{mEq} / \mathrm{L})$ & $4.8(3.5-5.0)$ \\
\hline $\mathrm{Cl}(\mathrm{mEq} / \mathrm{L})$ & 107 (98-108) \\
\hline BUN (mg/dL) & $30(8-20)$ \\
\hline $\mathrm{Cr}(\mathrm{mg} / \mathrm{dL})$ & $1.26(0.46-1.09)$ \\
\hline UA (mg/dL) & $10.0(\leq 7.0)$ \\
\hline $\mathrm{TP}(\mathrm{g} / \mathrm{dL})$ & $6.2(6.5-8.2)$ \\
\hline Alb (g/dL) & $4.4(3.7-5.5)$ \\
\hline $\mathrm{Ca}(\mathrm{mg} / \mathrm{dL})$ & $10.9(8.2-10.0)$ \\
\hline AST (U/L) & $32(10-40)$ \\
\hline ALT (U/L) & $36(5-45)$ \\
\hline T-Bil (mg/dL) & $0.3(0.2-1.0)$ \\
\hline LD (U/L) & 317 (I20-245) \\
\hline CRP $(\mathrm{mg} / \mathrm{dL})$ & $1.2(\leq 1.0)$ \\
\hline $\operatorname{lgG}(\mathrm{mg} / \mathrm{dL})$ & $248(820-1740)$ \\
\hline $\lg A(m g / d L)$ & $23(90-400)$ \\
\hline $\operatorname{lgM}(\mathrm{mg} / \mathrm{dL})$ & $27(3 \mid-200)$ \\
\hline BMG $(\mathrm{mg} / \mathrm{L})$ & $6.4(0.9-1.9)$ \\
\hline
\end{tabular}

Note: ( ): Normal ranges in the nearby hospital.

Abbreviations: ALT, alanine aminotransferase; AST, aspartate aminotransferase; CRP, C-reactive protein; $\mathrm{Hb}$, hemoglobin; $\mathrm{Ht}$, hematocrit; $\mathrm{Na}$, natrium; $\mathrm{K}$, kalium; $\mathrm{Cl}$, chlorine; $\mathrm{BUN}$, blood urea nitrogen; $\mathrm{Cr}$, creatinine; UA, urinary acid; TP, total protein; Alb, albumin; Ca, calcium; T-Bil, total bilirubin; LD, lactate dehydrogenase; BMG, $\beta 2$ microglobulin; Ig, immunoglobulin; RBC, red blood cell; Plt, platelet cell WBC, white blood cell.

had acute heart failure. His chest X-ray revealed cardiomegaly (cardiothoracic ratio was 59\%) with slight pulmonary congestion. Amino-terminal pro-brain natriuretic peptide levels were elevated to $811.2 \mathrm{pg} / \mathrm{mL}$. This acute heart failure was probably caused by cardiac amyloidosis, as cardiac ultrasound showed a granular sparkling pattern. However, the presence of amyloidosis was not confirmed by histological diagnosis. The patient's bone marrow aspirate was dry tap. A stamp preparation with his bone marrow biopsy showed $41.8 \%$ abnormal plasma cells. These cells were negative for cyclin D1, CD3, CD5, CD10, CD20, CD56, CD79a, and $\kappa$ chain, and positive for $\mathrm{CD} 138$ and $\lambda$ chain.

Chromosomal analysis showed normal karyotypes. No immunoglobulin H/cyclin D1 (IgH/BCL1) translocations were found in fluorescence in situ hybridization analysis. The patient was diagnosed with primary PCL based on these examina-
Table 2 Laboratory data upon admittance to research hospital

\begin{tabular}{|c|c|}
\hline Variable & On admission \\
\hline 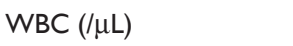 & $18,300(3,500-8,500)$ \\
\hline Neutrophils (\%) & $26(42-77)$ \\
\hline Lymphocytes (\%) & $18(18-49)$ \\
\hline Blasts (\%) & $0.5(0)$ \\
\hline Others (\%) & $40(0)$ \\
\hline Erythrocytes (/WI00) & $10(0)$ \\
\hline $\mathrm{RBC}\left(\times 10^{6} / \mu \mathrm{L}\right)$ & $253(400-570)$ \\
\hline $\mathrm{Hb}(\mathrm{g} / \mathrm{dL})$ & $8.5(12.9-17.2)$ \\
\hline $\mathrm{Ht}(\%)$ & $25.2(38.2-50.8)$ \\
\hline $\operatorname{Plt}\left(\times 10^{6} / \mu \mathrm{L}\right)$ & $2.9(14-34)$ \\
\hline $\mathrm{Na}(\mathrm{mEq} / \mathrm{L})$ & $143(138-146)$ \\
\hline $\mathrm{K}(\mathrm{mEq} / \mathrm{L})$ & $4.3(3.5-5.0)$ \\
\hline $\mathrm{Cl}(\mathrm{mEq} / \mathrm{L})$ & $109(100-110)$ \\
\hline BUN (mg/dL) & $14(8-20)$ \\
\hline $\mathrm{Cr}(\mathrm{mg} / \mathrm{dL})$ & $0.94(0.6-1.0)$ \\
\hline $\mathrm{UA}(\mathrm{mg} / \mathrm{dL})$ & $5.6(4.0-7.0)$ \\
\hline $\mathrm{TP}(\mathrm{g} / \mathrm{dL})$ & $6.2(6.5-8.2)$ \\
\hline Alb (g/dL) & $4.3(3.8-5.0)$ \\
\hline $\mathrm{Ca}(\mathrm{mg} / \mathrm{dL})$ & $8.7(8.5-10.3)$ \\
\hline AST (U/L) & $33(13-35)$ \\
\hline ALT (U/L) & $36(5-35)$ \\
\hline T-Bil (mg/dL) & $0.4(0.2-1.2)$ \\
\hline LD (U/L) & $396(112-230)$ \\
\hline CRP (mg/dL) & $0.278(0-0.3)$ \\
\hline $\lg G(\mathrm{mg} / \mathrm{dL})$ & $280(870-1700)$ \\
\hline $\lg \mathrm{A}(\mathrm{mg} / \mathrm{dL})$ & $15(110-410)$ \\
\hline $\operatorname{lgM}(\mathrm{mg} / \mathrm{dL})$ & $20(33-190)$ \\
\hline sIL-2R (U/L) & $1336(124-466)$ \\
\hline$\kappa / \lambda$ & $0.25(0.74-1.32)$ \\
\hline BMG (mg/L) & $4.7(0-2.0)$ \\
\hline
\end{tabular}

Note: ( ): Normal ranges in our laboratory.

Abbreviations: ALT, alanine aminotransferase; AST, aspartate aminotransferase; CRP, C-reactive protein; $\mathrm{Hb}$, hemoglobin; Plt, platelet cell; $\mathrm{Na}$, natrium; K, kalium; $\mathrm{Cl}$, chlorine; $\mathrm{BUN}$, blood urea nitrogen; $\mathrm{Cr}$, creatinine; UA, urinary acid; TP, total protein; Alb, albumin; Ca, calcium; T-Bil, total bilirubin; LD, lactate dehydrogenase; sIL-2R, soluble inter-leukin 2 receptor; BMG, $\beta 2$ microglobulin; $\mathrm{Ht}$, hematocrit; Ig, immunoglobulin; RBC, red blood cell; WBC, white blood cell.

tions. Treatment with a PAD regimen (bortezomib $1.3 \mathrm{mg} /$ $\mathrm{m}^{2}$ [days $1,4,8$, and 11], adriamycin $1.3 \mathrm{mg} / \mathrm{m}^{2}$ [days 1,4 , 8 , and 11], and dexamethasone $40 \mathrm{mg} /$ body [days $1-4,8-11$, and 15-18]) was started. As soon as the treatment was started, leukemic plasma cell levels rapidly decreased (Figure 1). No organ dysfunction was detected, except that serum creatinine levels temporarily increased to $1.21 \mathrm{mg} / \mathrm{dL}$. On day 27 of the first PAD cycle, the leukemic plasma cells in peripheral blood disappeared. In addition, hemoglobin and platelet levels were improved to normal levels. After three PAD cycles, we were unable to assess his bone marrow, because it remained dry tap. Serum $\kappa / \lambda$, a surrogate marker for the treatment effect of this case, became similar to normal levels. In addition, the granular sparkling pattern detected by cardiac ultrasound at the time of admission disappeared. The patient was then 


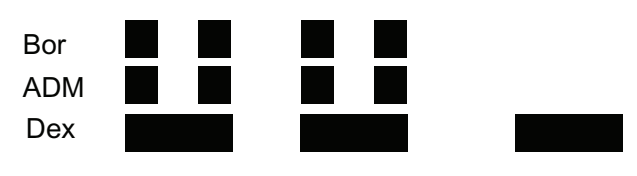

$(/ \mu \mathrm{L})$

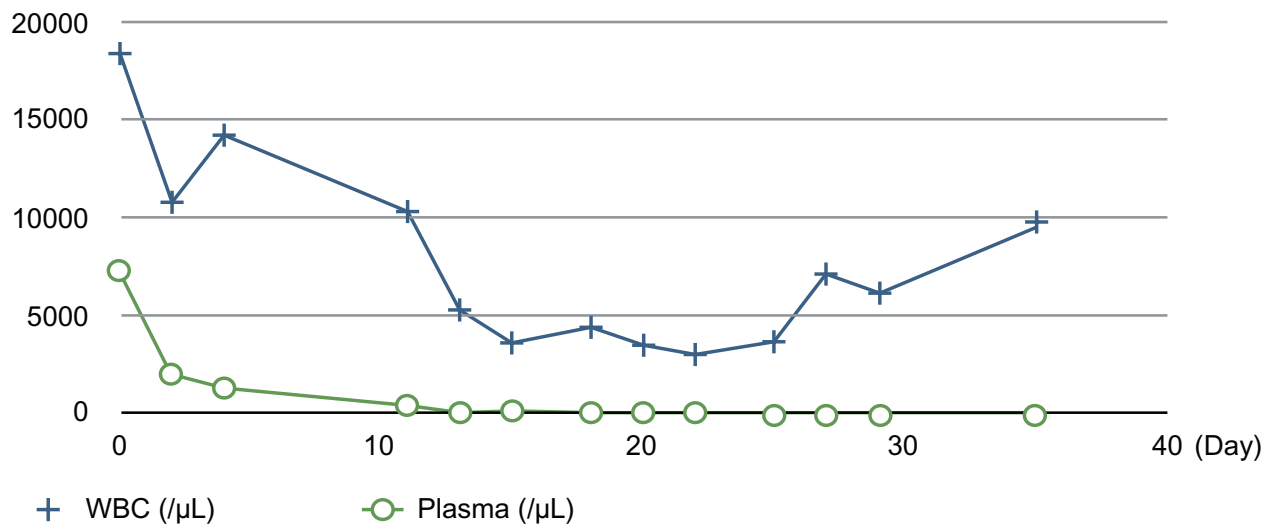

Figure I The clinical course of Ist PAD.

Abbreviations: Bor, bortezomib; ADM, adriamycin; Dex, dexamethasone; WBC, white blood cell.

administered high-dose therapy (HDT) + ASCT. Before HDT + ASCT, his peripheral blood stem cells containing $10.9 \times 10^{6} /$ $\mathrm{kg}$ CD34-positive cells were harvested with high-dose cyclophosphamide. He received HDT + ASCT with a conditioning regimen of high-dose melphalan $\left(100 \mathrm{mg} / \mathrm{m}^{2}\right.$ [days -3 and -2]) and bortezomib ( $1 \mathrm{mg} / \mathrm{m}^{2}$ [days $-7,-4,+1$, and +4$\left.]\right)$. At the end of HDT $+\mathrm{ASCT}$, serum $\kappa / \lambda$ remained at normal levels. Sixty-seven days after HDT + ASCT, the patient received allogeneic bone marrow stem cell transplantation (allo-BMT) from his human leukocyte antigen-matched brother, containing $2.1 \times 10^{8} / \mathrm{Pt} \cdot \mathrm{kg}$ nuclear cells and $1.44 \times 10^{6} / \mathrm{Pt} \cdot \mathrm{kg}$ CD34-positive cells. The conditioning regimen consisted of fludarabine $\left(30 \mathrm{mg} / \mathrm{m}^{2}\right.$ [day -6 to day -2 ]) and total body irradiation (2 Gy [day-1]). Graft-versus-host disease (GVHD) prophylaxis included tacrolimus and short-term methotrexate. Neutrophils were engrafted on day 9. The patient achieved complete donor chimerism by the time of discharge. There were no complications during the treatment period. Twelve months after allo-BMT, the patient's serum $\kappa / \lambda$ level was maintained at normal levels. He remained in a state of remission, with only the complication of mild skin GVHD.

\section{Discussion}

There are no established therapeutic regimens for PCL. Several regimens that include an alkylating agent are sufficient to improve the overall survival (OS) of PCL patients. Jiménez-Zepeda and Domínguez reported a median OS of 6.8 months for PCL patients treated with a common chemotherapy regimen consisting of vincristine, adriamycin, and dexamethasone, versus 2 months for those who received melphalan and prednisolone. ${ }^{5}$ It has also been reported that a combination of intermediate doses of melphalan and dexamethasone obtained the highest level of response in PCL patients. However, the median OS was only 60 days for the cohort that achieved a partial or complete response. ${ }^{6}$

By comparison, bortezomib regimens show promise as induction regimens for PCL. Katodritou et al reported that a combination of bortezomib and dexamethasone prolonged OS (median, 12 months). ${ }^{7}$ The efficacy of PAD has been reported by Chan et al. ${ }^{8}$ Similar to the case presented by Chan et al, our case, inducted with PAD, showed a very impressive clinical course. As soon as PAD was started, leukemic plasma cell levels rapidly decreased (Figure 1). In addition, anemia and platelet depletion improved, and acute heart and kidney dysfunction rapidly recovered. After three PAD cycles, serum $\kappa / \lambda$ levels were normalized, without any adverse effects (Figure 2). In the present case, the absolute values of the immunoglobulin $\kappa / \lambda$ free light chains in the serum before and after therapy had to be very important. However, we could not measure these data. Although PAD is effective for PCL, it remains to be determined whether long-term survival is improved, because of a lack of longterm follow-up. Immunomodulatory drugs (IMiDs), such as thalidomide and lenalidomide, are as promising as bortezomib. ${ }^{9,10}$ The reasons we did not choose IMiDs were that lenalidomide was not approved in Japan at the onset of the 


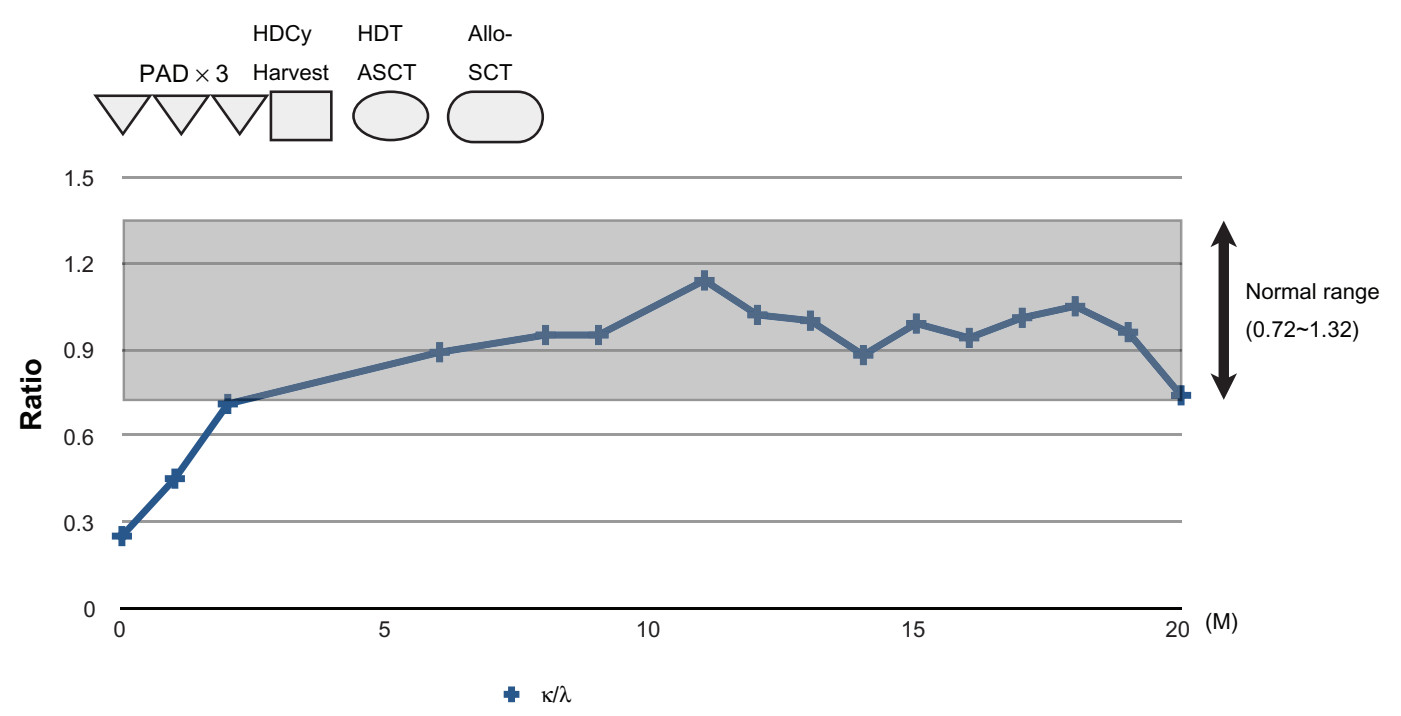

Figure 2 The overall clinical course of this case.

Abbreviations: HDT, high-dose therapy; ASCT, auto stem cell transplantation.

patient's PCL, and we decided to leave an opportunity to use thalidomide at his relapse.

Our case represented a potential curative strategy for PCL, with the safe introduction of allo-immunization with a nonmyeloablative regimen following PAD and HDT + ASCT. For multiple MM, the most common malignant disease in plasma cells, ASCT is regarded as the standard therapy for newly diagnosed cases in patients younger than 65 years. However, few patients who undergo the procedure are free of disease for more than 10 years. On the other hand, allo-SCT is a promising therapy. Because of the graftversus-myeloma effect, a lower relapse rate and longer remissions have been reported in patients receiving allo-SCT. ${ }^{11}$ Presumably, PCL may be the same as MM. However, the high risk of transplant-related mortality $(30 \%-60 \%)$ is a limitation of the use of allo-SCT for MM. To overcome this limitation, Maloney et al reported that combining a cytoreductive autograft with a nonmyeloablative allograft lowered transplant-related mortality by approximately $15 \%{ }^{12}$ Meanwhile, Ramasamy et al reported that alemtuzumabbased reduced intensity conditioning allogeneic transplantation. ${ }^{13}$ Although progression-free survival of their patient cohort was comparable to previously published data of reduced intensity conditioning allogeneic transplantation in myeloma, there is no plateau on the survival curves, with a significant transplant-related mortality of $21 \%$.

PCL is more frequent in subjects aged over 60-65 years. Although nonmyeloablative conditioning reduces transplantrelated mortality, it is difficult for patients older than 65 years to use our strategy. For them, induction regimen with bortezomib and maintenance regimen with IMiDs may be appropriate.
We have a successful case of newly diagnosed primary PCL, treated with a regimen that included bortezomib and ASCT, followed by nonmyeloablative allo-SCT. Our patient has maintained remission status for over 12 months since allo-SCT. This strategy is promising for PCL, which, though an extremely resistant disease, may become curable.

\section{Disclosure}

The authors declare no conflicts of interest in this work.

\section{References}

1. Dimopoulos MA, Palumbo A, Delasalle KB, Alexanian R. Primary plasma cell leukaemia. Br J Haematol. 1994;88(4):754-759.

2. Kyle RA, Maldonado JE, Bayrd ED. Plasma cell leukemia. Report on 17 cases. Arch Intern Med. 1974;133(5):813-818.

3. International Myeloma Working Group. Criteria for the classification of monoclonal gammopathies, multiple myeloma and related disorders: a report of the International Myeloma Working Group. Br J Haematol. 2003;121(5):749-757.

4. Noel P, Kyle RA. Plasma cell leukemia: an evaluation of response to therapy. Am J Med. 1987;83(6):1062-1068.

5. Jiménez-Zepeda VH, Domínguez VJ. Plasma cell leukemia: a rare condition. Ann Hematol. 2006;85(4):263-267.

6. Vela-Ojeda J, García-Ruiz Esparza MA, Rosas-Cabral A, et al. Intermediate doses of melphalan and dexamethasone are better than vincristine, adriamycin, and dexamethasone (VAD) and polychemotherapy for the treatment of primary plasma cell leukemia. Ann Hematol. 2002;81(7):362-367.

7. Katodritou E, Verrou E, Gastari V, Hadjiaggelidou C, Terpos E, Zervas K. Response of primary plasma cell leukemia to the combination of bortezomib and dexamethasone: do specific cytogenetic and immunophenotypic characteristics influence treatment outcome? Leuk Res. 2008;32(7):1153-1156.

8. Chan SM, George T, Cherry AM, Medeiros BC. Complete remission of primary plasma cell leukemia with bortezomib, doxorubicin, and dexamethasone: a case report. Cases J. 2009;2(1):121.

9. Wohrer S, Ackermann J, Baldia C, et al. Effective treatment of primary plasma cell leukemia with thalidomide and dexamethasone - a case report. Hematol J. 2004;5(4):361e-336e. 
11. Corradini P, Voena C, Tarella C, et al. Molecular and clinical remissions in multiple myeloma: role of autologous and allogeneic transplantation of hematopoietic cells. J Clin Oncol. 1999;17(1):208-215.

12. Maloney DG, Molina AJ, Sahebi F, et al. Allografting with nonmyeloablative conditioning following cytoreductive autografts for the treatment of patients with multiple myeloma. Blood. 2003;102(9):3447-3454.
13. Ramasamy K, Mahmood S, Lim Z, et al. Alemtuzumab-based reducedintensity conditioning allogeneic transplantation for myeloma and plasma cell leukemia - a single-institution experience. Clin Lymphoma Myeloma Leuk. 2011;11(2):242-245.

International Medical Case Reports Journal

\section{Publish your work in this journal}

The International Medical Case Reports Journal is an international, peer-reviewed open-access journal publishing original case reports from all medical specialties. Previously unpublished medical posters are also accepted relating to any area of clinical or preclinical science. Submissions should not normally exceed 2,000 words or
4 published pages including figures, diagrams and references. The manuscript management system is completely online and includes a very quick and fair peer-review system, which is all easy to use. Visit http://www.dovepress.com/testimonials.php to read real quotes from published authors.

Submit your manuscript here: http://www.dovepress.com/international-medical-case-reports-journal-journal 